\title{
Quiescent-phase evolution of a surge-type glacier: Black Rapids Glacier, Alaska, U.S.A.
}

\author{
T. A. Heingichs, L. R. Mayo, \\ U.S. Geological Survey, 800 Tukon Dr., Fairbanks, Alaska 99775-5170, U.S.A. \\ K. A. Echelmeyer and W. D. Harrison \\ Geophysical Instilule, University of Alaska, 903 Koyukuk Dr., Fairbanks, Alaska 99775-7230, U.S.A.
}

\begin{abstract}
Black Rapids Glacier, a surge-type glacier in the Alaska Range, most recently surged in 193637 and is currently in its quiescent phase. Mass balance, ice velocity and thickness change have been measured at three to ten sites from 1972 to 1994. The annual speed has undergone cyclical fluctuations of as much as $45 \%$ about the mean speed. Ice thickness and surface slope did not change enough to cause the speed fluctuations through changes in ice deformation, which indicates that they are being driven by changes in basal motion. The behavior of Black Rapids Glacier during this quiescent phase is significantly different from that of Variegated Glacier, another well-studied surge-type glacier in Alaska. The present medial-moraine configuration of Black Rapids Glacier indicates that a surge could occur at any time. However, ice velocity data indicate that the next surge may not be imminent. We believe that there is little chance that the next surge will cross and dam the Delta River.
\end{abstract}

\section{INTRODUCTION}

A surge-type glacier lies quiescent for decades, growing stceper and accumulating mass in its ice reservoir area in preparation for its next surge (Meier and Post, 1969). Considerable effort has gone into studies of a few surgetype glaciers during their quiescent phases and during their surges. Only Variegated Glacier in the St Elias Mountains of Alaska, Medvezhiy glacier in the Pamirs of Tadzhikistan, and West Fork Glacier in the Alaska Range have been quantitatively observed for extended intervals between and during their surges Dolgushin and Osipova, 1975, 1978; Bindschadler and others, 1977; Kamb and others, 1985; Raymond and Harrison, 1988; Harrison and others, 1994).

This paper presents a 24 year data set of ice velocity, ice thickness change and mass balance gathered from 1970 to 1994 during the present, ongoing quiescent phase of Black Rapids Glacier (Fig. 1), a surge-type glacier in the Alaska Range. Here we distill and interpret the data published by Heinrichs and others (1995), which contain a full compilation of the observations of the glacier made by the U.S. Geological Survey and University of Alaska Fairbanks. In the analysis here, the effect of mass balance on surface elevation is considered, and, using observations of glacier geometry change, ice-stresses calculations are made in an attempt to understand observed variations in ice speed in terms of internal ice deformation and basal motion.

Black Rapids Glacier most recently surged in 1936-37, and has an estimated surge period of $50-75$ years. The estimate is based on the following evidence. First, air photos show a series of looped moraines on the glacier. A well-preserved, looped moraine generated at the mouth of the Loket tributary and carried down-glacier during the 1936-37 surge encloses about the same surface area as that present within the current loop generated in the 57 years between 1937 and 1994 Fig. 2 and U.S. Army Trimetragon photo F1.56-R158, 1 August 1942). Secondly, two nearby glaciers, West Fork and Susitna Glaciers, most recently surged with periods of 50 -60 years between surges (T.S. Clarke, 1991; Harrison and others, 1994). Assuming that the local climate influences the rate of recharge between surges, Black Rapids Glacier could be expected to have a surge period similar to its neighboring glaciers.

\section{Black Rapids Glacier and its surroundings}

Black Rapids Glacier is located in the central Alaska Range, just south of some of the highest mountains in that part of the range: Mount Shand, $3859 \mathrm{~m}$ (Fig. 1); Mount Hayes, $4216 \mathrm{~m}$; and Mount Moffit, $3968 \mathrm{~m}$. The ablation area lies in an east west running valley carved in the Denali Fault trench; most of the accumulation area is in two north-facing valleys. The more easterly of these two valleys is a major tributary glacier unofficially known as the "Loket tributary" (Fig. 1). Other smaller tributaries contribute to the main ice stream, as indicated by the moraine patterns shown in Figure 1. Based on a 1973 map (Fig. 1), the total area of the glacier, including tributaries, is $246 \mathrm{~km}^{2}$. An additional $31 \mathrm{~km}^{2}$ of glacier ice not 


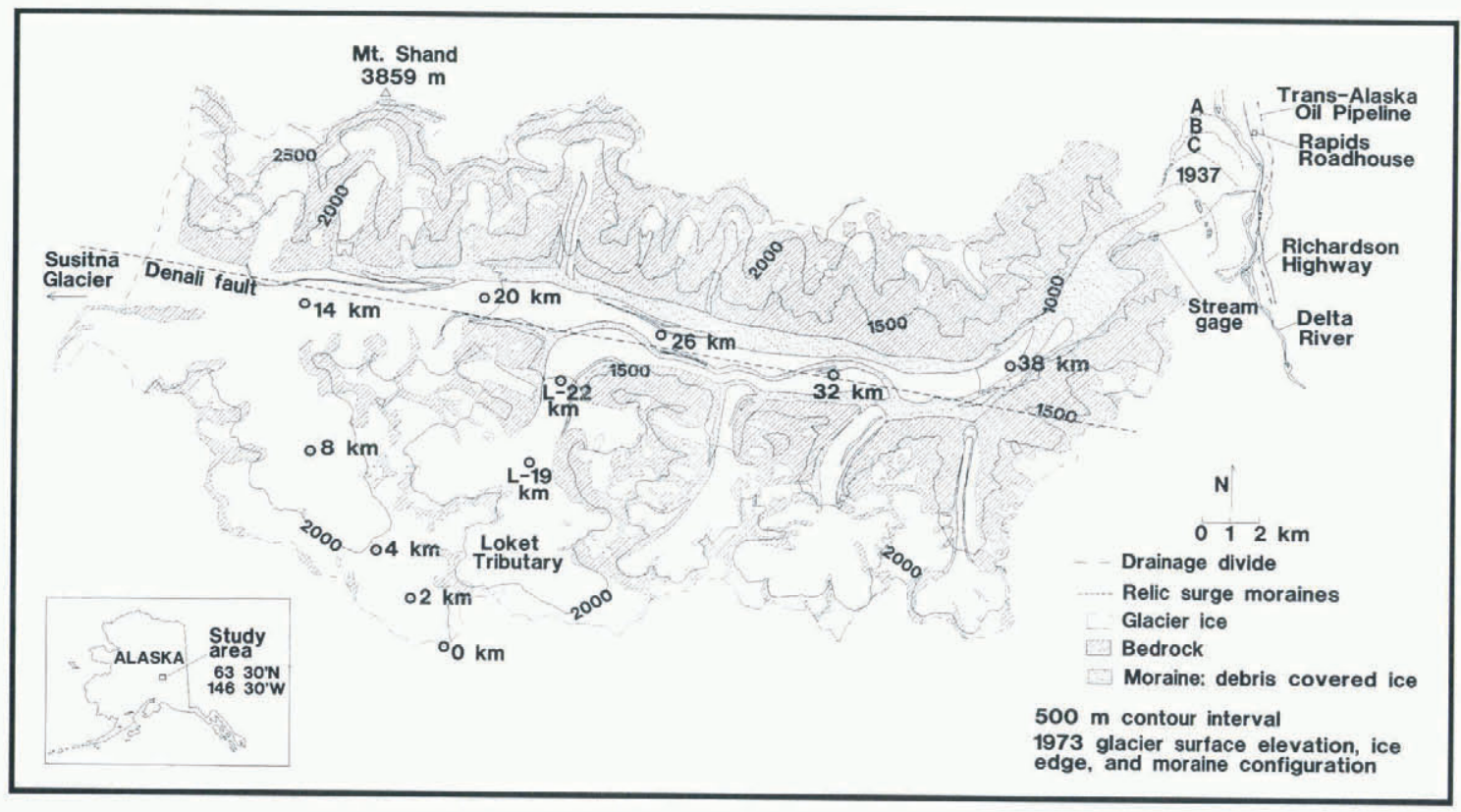

Fig. 1. Map of Black Rapids Gilacier, Alaska, U.S.A., showing stream gage ( $\oplus)$, index sites ( $\odot)$, surface moraines and moraines formed by previous surges. Center-line coordinate system originates at the head of the glacier and extends longitudinally down the center of the glacier. Glacier surface elevations are from Heinrichs and others (1995). Holocene moraine positions and dates are after Reger and others (1993), and the best estimates for the minimum dates of the relic surge moraines are A: $3360 \mathrm{BP}, \mathrm{B}: 1710 \mathrm{BP}$, and $\mathrm{C}: 570 \mathrm{BP}$ (or $210 \mathrm{BP}$ ).

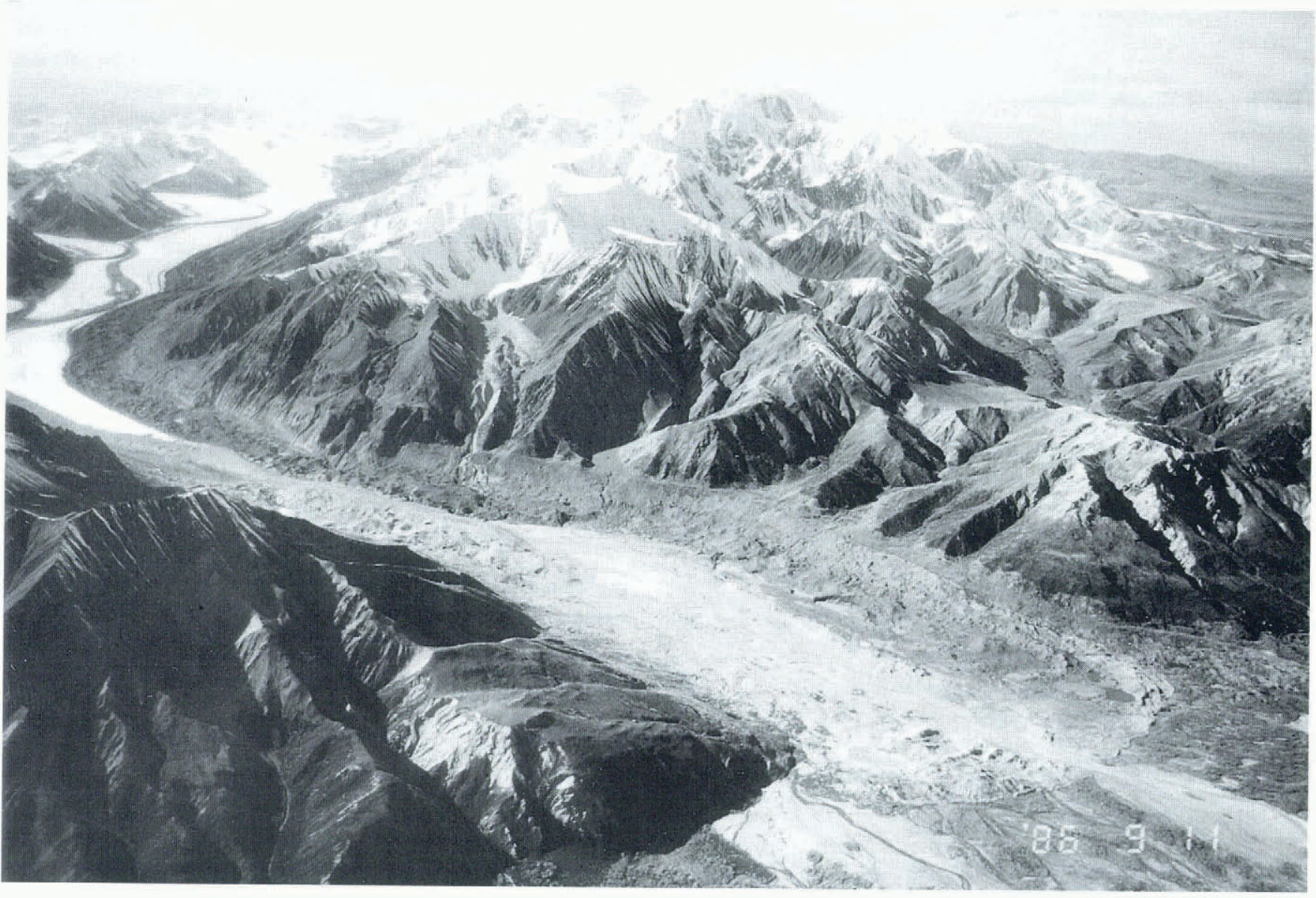

Fig. 2. Pholograph of Black Rapids Glacier, Alaska, laken on 11 Seplember 1986. The extent of the 1936 -37 surge advance and the 1986 terminus can be seen in the foreground. Note the looped medial moraine at the mouth of the Lokel tributar (Fig. 1) and the loop formerly at the mouth of the tributary which was carried down-glacier during the 193637 surge. (Photograph taken by R.S. March. LiS(iS.) 
connected to Black Rapids Glacier is also in the drainage basin. The drainage basin area is $473 \mathrm{~km}^{2}$; its lower boundary is defined by the stream-gauging site cstablished by the Universities of Alaska and Washington (Fig. 1). Water draining from the glacier basin enters the Delta River.

Measurement locations in this report are referred to a center-line curvilinear coordinate system with the origin at the had of the glacier (Fig. 1). Measurement sites are referred to as "the $14 \mathrm{~km}$ site", for example. A secondary center-line coordinate system is used for the Loket tributary (Fig. 1). Its origin is at the $26 \mathrm{~km}$ site on the main branch, and the sites are referred to as "the L-19km site", for example.

In 1992, the length of main reach of the glacierfrom the top of the principal accumulation area, at the site marked as $0 \mathrm{~km}$ in Figure 1, to the terminus - was about $43 \mathrm{~km}$. Ice-cored moraine remnants from the 1936 37 surge lay $4 \mathrm{~km}$ in front of the 1992 terminus and within $1 \mathrm{~km}$ of the Delta River. Glacier geometry is summarized in Figure 3. The glacier is temperate Harrison and others, 1975).

The geologic setting of Black Rapids Glacier could be an important factor contributing to its surge nature (Post, 1969). A substantial part of the glacier lies along the Denali Fault, a major fault extending hundreds of kilometers through the Alaska Range (Post, 1969; Nokleberg and others, 1992). Two other surge-type glaciers, Sustina and West Fork Glaciers, also lie along the Denali Fault near Black Rapids (T.S. Clarke, 1991; Harrison and others, 1994).

\section{History of Black Rapids Glacier surges}

A surge of Black Rapids Glacier in 1936-37 was first observed during November 1936; the surge had started at some earlier, unknown date. The terminus had

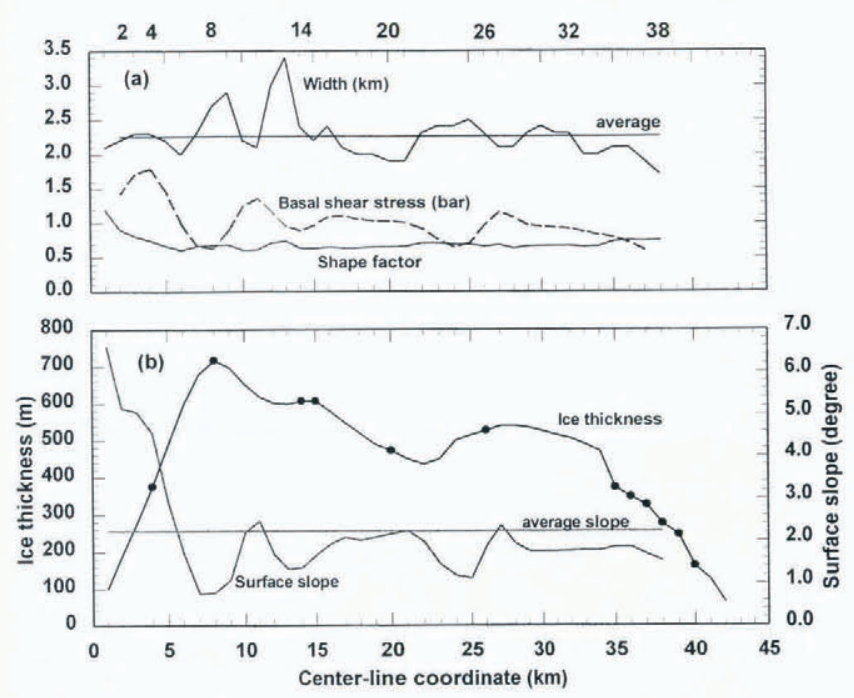

Fig. 3. Longitudinal variation of width, basal shear stress, shape factor, ice thickness and surface slope in 1977. Ice thickness was measured al points (•) along the center line (Heinrichs and others, 1995); elsewhere, they were estimated. Surface slope was interpolated from USGS quadrangle maps and 1977 geodetic surveys. stopped advancing by September 1937 (Moffit, 1939). The Loket tributary and all but one south-side tributary participated in the surge. (The farthest east, now disconnected, south tributary did not surge in 1936-37.) The two south-facing tributaries nearest to the $14 \mathrm{~km}$ site (Fig. 1) surged as well. Oblique air photos made in 1942 show large crevasses to within $3 \mathrm{~km}$ of the head of the main branch (U.S. Army Trimetragon photo Fl.56-L157, 1 August 1942). No photos show the area above $3 \mathrm{~km}$, so it is unknown to what extent the upper $3 \mathrm{~km}$ of the glacier participated in the surge. The 1942 photos also show large crevasses to the top of the Loket tributary (U.S. Army Trimetragon photo Fl.56-V156, 1 August 1942).

During the 1936-37 surge, the terminus of Black Rapids Glacier advanced as a lobe of ice out of the mouth of its valley into the relatively wide and flat Delta River valley, and ultimately stopped advancing about $500 \mathrm{~m}$ from the Delta River (Fig. 1; Hance, 1937; Moffit, 1939; O. Geist, as reported by Giddings (1988) and Heinrichs (1994)). Moffit summarized bystanders observations which indicate the glacier advanced approximately 4 miles $(6.4 \mathrm{~km})$ between 3 December 1936 and 7 March 1937. The 1936-37 surge advanced $100200 \mathrm{~m}$ beyond the surge moraine left by the surge immediately prior to it 1929 photograph from the Otto Geist collection at the University of Alaska Fairbanks, series $\mathrm{X}$, Box 1 ).

The potential threat of Black Rapids Glacier became an issuc in 1968 prior to the construction of an oil transport pipeline across Alaska from Prudhoe Bay on the Arctic Ocean to Port Valdez near the Gulf of Alaska. Relic moraines of advances prior to 1937 clearly indicate that the glacier has crossed the Delta River valley in the past, creating a glacier-dammed lake which would threaten the pipeline (Post and Mayo, 1971). Three moraines created by Holocene advances (A, B, C in Figure 1) have been studied by Reger and others (1993). They suggested that the moraine composition indicates a surge origin for $\mathrm{A}$ and $\mathrm{B}$; they could not be sure that $\mathrm{C}$ was formed by a surge. The surges which formed $A$ and $B$ crossed and dammed the Delta River; the advance associated with $\mathrm{C}$ may have. They estimated minimum ages for the moraines: $3360 \pm 120 \mathrm{BP}, 1710 \pm 85 \mathrm{BP}$, and $570 \mathrm{BP}$ (or possibly as young as $210 \mathrm{BP}$ ) for A, B and $\mathrm{C}$, respectively.

\section{OBSERVATIONS OF SPEED, GEOMETRY AND MASS BALANCE}

\section{Measurements: history and techniques}

Black Rapids Glacier has been monitored with varying degrees of intensity from 1970 through the present as a joint effort of the U.S. Geological Survey (USGS), University of Alaska Fairbanks (UAF) and University of Washington (UW). Mass-balance, ice-velocity and surface-elevation observations gathered at ten index sites by the USGS comprise most of the data appearing here. Eight of those sites are on the main branch of the glacier and two are in the Loket tributary. The number of sites monitored has been reduced since 1987 . 
In addition to the base-line measurements at the index sites, other quantities have been measured: ice thicknesses and several velocity cross-profiles Heinrichs and others, 1995). Raymond and others (1995) observed stream hydrology (stage, electrical conductivity and suspendedsediment concentration), measured short-time-scale ice motion using time-lapse photography and made hourly observations of vertical strain and seismicity. The history and behavior of the "potholes" located in the pass between Black Rapids and Susitna Glaciers have also been described Sturm, 1987; Sturm and Cosgrove, 1990. Oblique air-photo flights were made by the USGS, starting in the 1960 s. Flights were made almost every year between 1971 and 1982.

A map approximating the 1973 glacier surface configuration (Fig. 1; for a more detailed map, see Heinrichs and others, 1995 was made because the glacier surface has changed substantially since the date of photography for the topographic maps available 1948 49 and 1954 for the USGS Mount Hayes B-4 quadrangle, and 1950 and 1956 for the USGS Mount Hayes B-5 quadrangle). The 1973 map (Fig. 1) was not made using photogrammetric methods; rather, the glacier surface contours were sketched using 133 points surveyed on the glacier surface during 1973 and 1976 Heinrichs and others, 1995, fig. 9. The 1973 map is qualitatively correct, but there could be substantial quantitative errors, particularly in regions of the glacier where no surveying was done.

The ten sites along the glacier center line chosen for long-term observations are referred to as index sites Fig. 1). The index sites have fixed horizontal coordinates (Heinrichs and others, 1995, table 21). Measurements at each site were made very near a single point on the glacier and thus constitute measurements in a reference frame fixed in space. Extensive tables of the observations stake readings, snow-probing depths, displacement vectors. etc.) and operational details are available in the report by Heinrichs and others 1995 . The data gathered from 1973 to 1994 are shown in Figure 4. Estimated uncertainties can be found in Table 1.

Table 1. Uncertainties associated with the net mass balance, index-sile elevation and speed resulls. Most of the uncerlainty in the accumulation-area mass-balance results arises from the need to estimate firm density. Most of the uncerlainty in the elevations and velocities is due 10 uncerlainty in the vertical component of optical survers caused by the variability of refiaction in the almosphere. Delailed uncerlainty calculations can be found in Heimrichs and olhers (1995)

Quantily

Estimaled uncerlain!)

Net mass balance

Ablation area

Accumulation area

Index-site elevation

Ice speed

$0.050 .10 \mathrm{mw}$.e.

$0.280 .44 \mathrm{mw} . \mathrm{e}$.

$0.35 \mathrm{~m}$

0.37 mear $^{1}$

\section{Speed}

Speed fluctuations, with acceleration and deceleration episodes of 49 years, are the most prominent features of the velocity data sets (Fig. 4). During the period of observation, speed at all of the sites with full records has undergone two periods of decrease (1973-77 and 1987 90 and two periods of increase (1978 86 and 1991-94). These fluctuations are coherent in phase on the main branch of the glacier, with the largest amplitudes observed at the two sites highest in the ablation area 14 and $20 \mathrm{~km}$; Fig. $4 \mathrm{~d}$ and e).

"Annual speed" (Fig. 4) in this paper is the speed measured between successive spring generally April observations. During the 197886 speed-up, the annual speed increase was largest at three of the four sites between 14 and $32 \mathrm{~km}$ (Fig. 5). These three sites 14,20 and $32 \mathrm{~km}$ lie along the Denali Fault Fig. 1). The 14 and $20 \mathrm{~km}$ sites have undergone very similar changes in speed, but the speed at the $14 \mathrm{~km}$ site is about $10 \mathrm{~m}$ year ${ }^{1}$ higher (Fig. 6). The fourth site, $26 \mathrm{~km}$, showed smaller fractional speed changes than the other three sites in the $14.32 \mathrm{~km}$ reacl. The magnitude of the speed changes at $26 \mathrm{~km}$ fits better with the changes observed at the Loket tributary sites (Fig. 5 ).

At $8 \mathrm{~km}$, in the accumulation area, speed fluctuations were in phase with those at 14 and $20 \mathrm{~km}$ but not as large. Ice thickness was increasing continuously at the $8 \mathrm{~km}$ site during these speed fluctuations (Fig. 4c). The more variable seasonal speeds at $4 \mathrm{~km}$ appear to cause increased variability in annual speeds.

The Loket tributary sites $\mathrm{L}-19$ and L-22 km) showed smaller speed changes than the two sites on the main branch with comparable elevations 14 and $20 \mathrm{~km}$; Fig. 5). Both Loket sites showed a significant increase in speed during 1983, the year after a speed-up occurred at 14 and $20 \mathrm{~km}$; these increases were relatively small in terms of fractional change. In the Loket tributary, the ice was thinning during the period of the speed increase; thickening began at a small rate at $\mathrm{L}-22 \mathrm{~km}$ in 1984 and at L-19 in 1987.

"Scasonal speed" in this paper is the speed measured between successive "spring" and "autumn" field trips. The "summer" observation season was typically between April and September, and the "winter" season was from September to April. Some caution is required when discussing seasonal speeds because they are calculated only for the period between observations, and the observations were not made on exactly the same date every year. Consequently, each observation contains a slightly different mix of summer and winter speeds. The data are not adjusted to account for these differences.

The seasonal-speed time-series data Fig. 4) exhibit several notable features. One is the prominent increase in summer speed during 1979 at all observed sites. Another especially significant aspect is that long-term fluctuations occur in both the winter and summer speeds; the winter and summer speeds rise and fall together, and the difference between the winter and summer speeds remains constant.

The sites with the largest differences in speed between the winter and summer seasons are the same sites that underwent the largest long-term changes in annual speed. 
(a) $2 \mathrm{~km}$ site

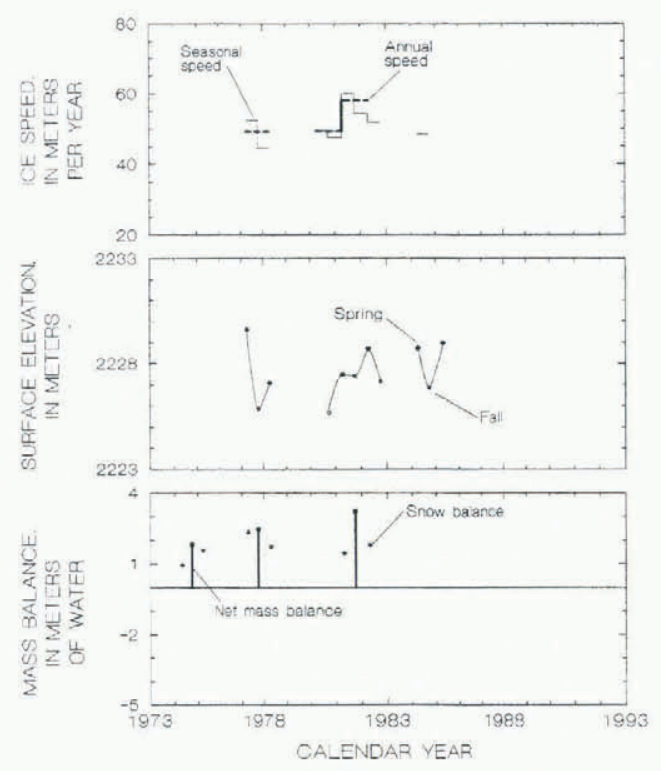

(c) $8 \mathrm{~km}$ site

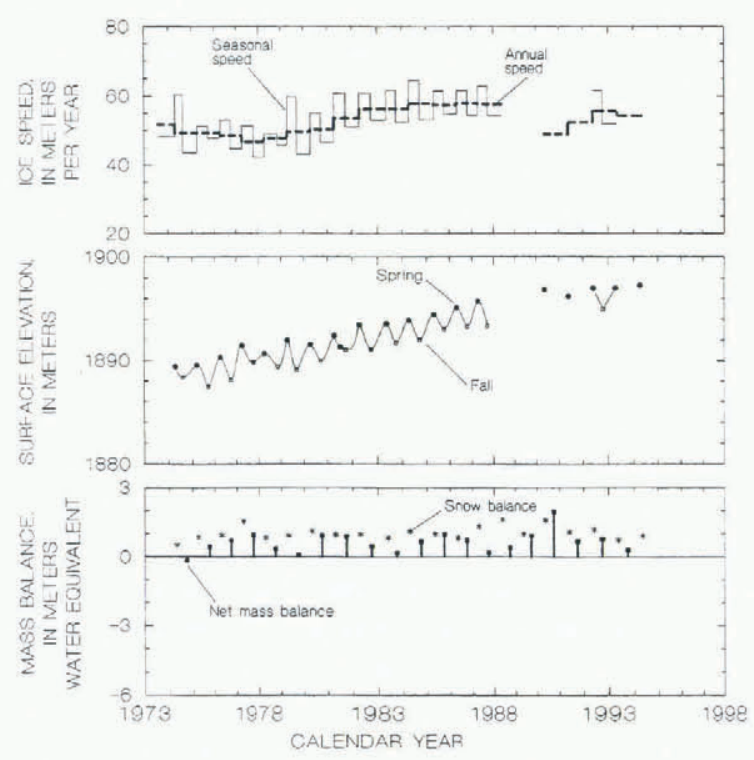

(e) $20 \mathrm{~km}$ Site

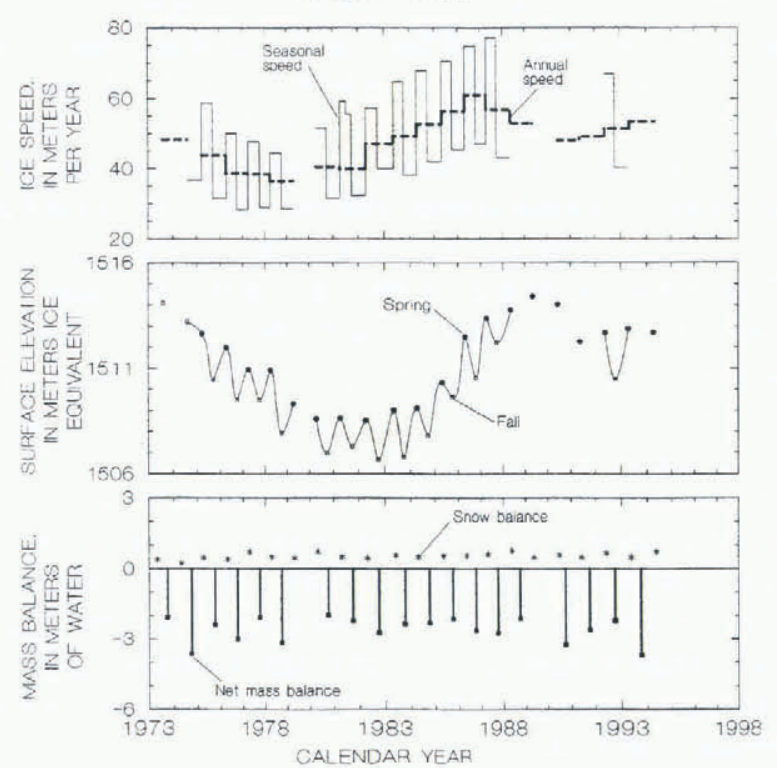

(b) $4 \mathrm{~km}$ Site

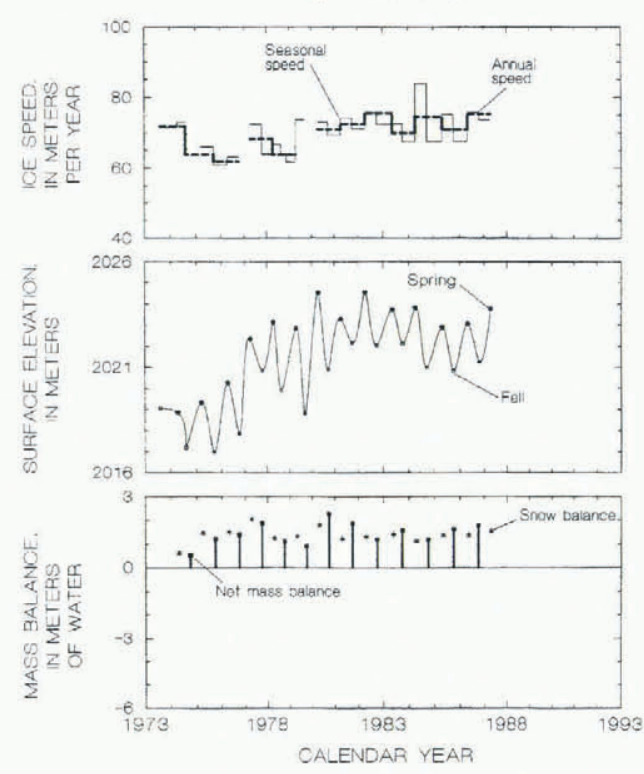

(c) $14 \mathrm{~km}$ Site
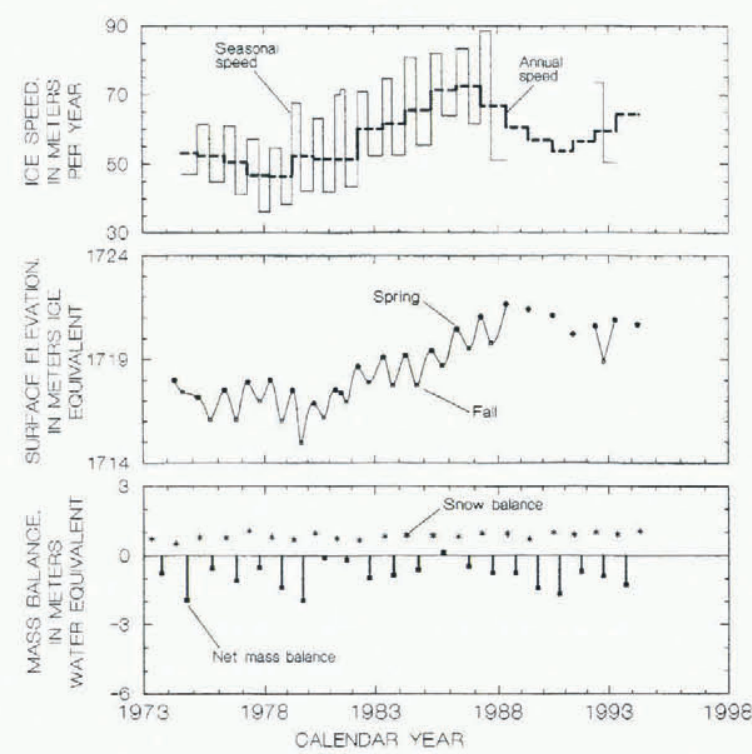

(f) $26 \mathrm{~km}$ Site

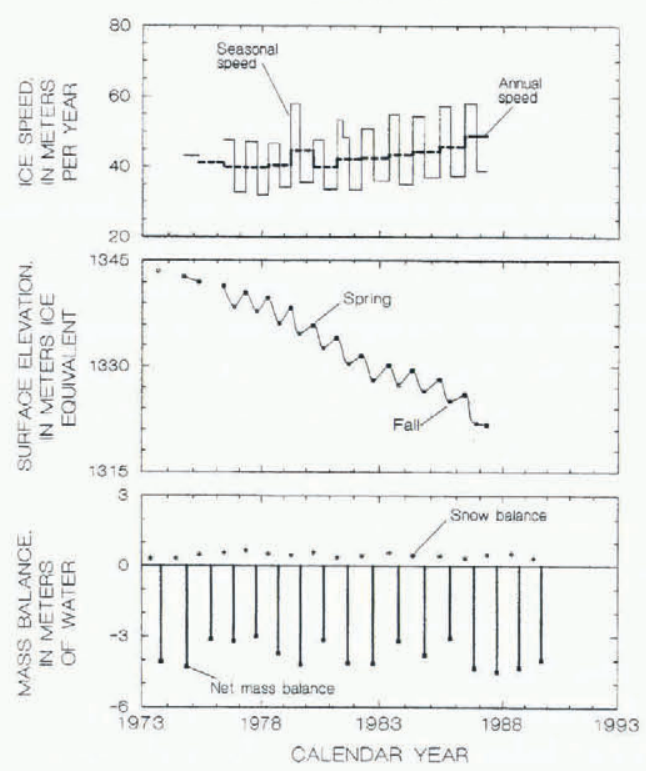

Fig. 4a f. Index-sile ice speed, surface elevation and net mass balance at Black Rapids Glacier at each site shown in Figure 1. See Fig. $4 g$ - $j$ caption for delails. 
(g) $32 \mathrm{~km}$ Site

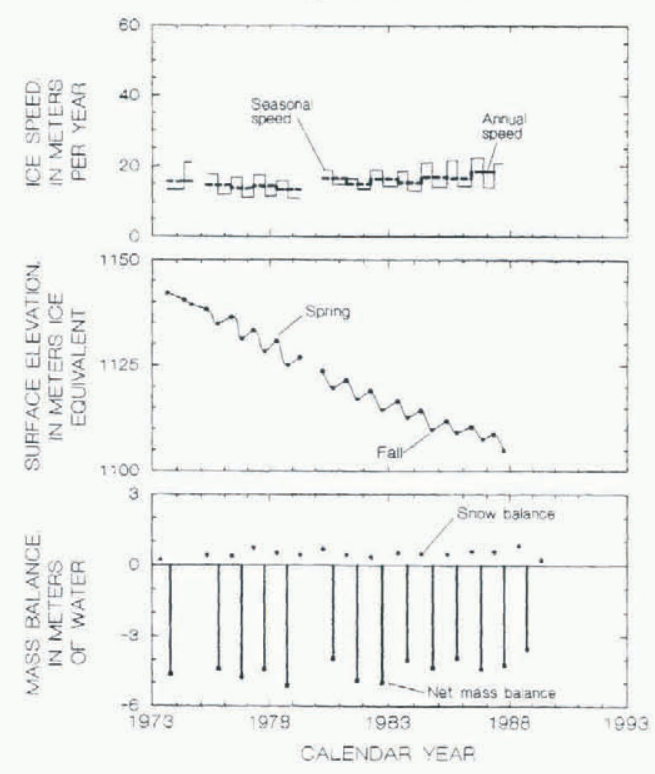

(i) $L-19 \mathrm{~km}$ Site

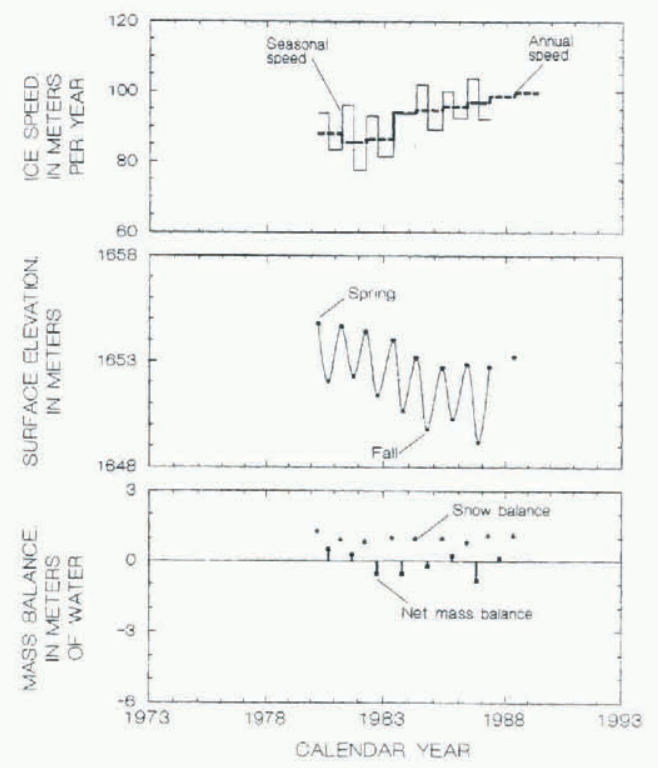

(n) $38 \mathrm{~km}$ Site

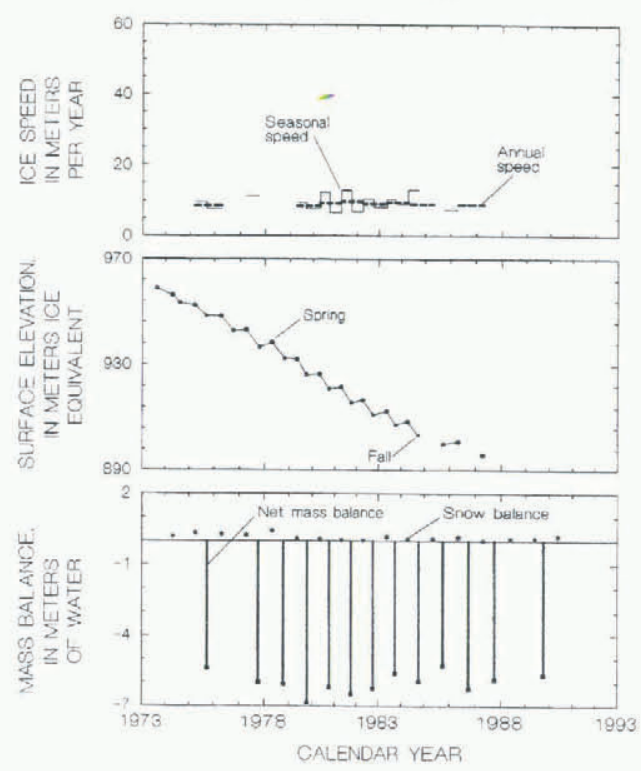

(j) $L-22 \mathrm{~km}$ Site

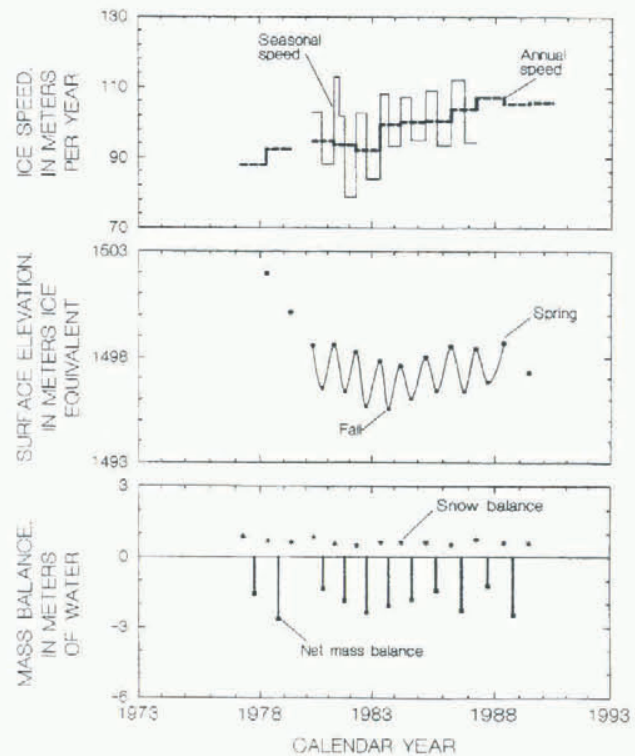

Fïg. Ag-j. Index-site ice speed, surface eleration and net mass balance al Black Rapids Gilacier at each sile shou'n in F̈̈gure 1. Ablation-area surface elezations are "ice equivalent". which is the ice surface elevation plus the thickness of the smow' converted to its equivalent thickness of ice. (. Measured surface elevations can be found in Heimrichs and olhers (199.5).) .11 the 2, 4,8 and L-1.9km sites, the measured surface elevalions are plotled. Snow balances are plotled on the date of abservation. The net balance for a year is plotled al $3 / 4$ of the way through the vear. For evample, the 1978 net mass balance is plolled al 1978.7.5.

We define the "seasonal-speed difference" as the difference between summer and winter speeds. It is the peak-to-peak amplitude of the yearly difference in seasonal speed seen in Figure 4. Comparing the average scasonal speed differences at each site, for the period of record, with the long-term increase in speed from 1978 to 1986 shows that the magnitude of the average seasonalspeed difference is correlated with the size of the longterm change in annual speed at a site (Fig. 7).

\section{Surface elevation and ice thickness}

Figure 3 shows the glacier geometry in September 1977 based on elevation surveys at the ten index sites. Ice thicknesses were measured at some locations using icepenetrating radar Heinrichs and others, 1995, table 17 : measured values are marked with dots in Figure 3 . Ice thicknesses were estimated at points between measurements using a combination of curve fitting and depth estimates based on surface morphology. The estimated uncertainty for measured values of ice thickness is $\pm 10 \%$, and of unmeasured values is $\pm 20 \%$, based upon our judgment.

Between 1979 and 1986, the glacier thinned at a much higher rate low on the glacier than it thickened up-glacier Fig. 8a). The surface elevation difference between a 1977 


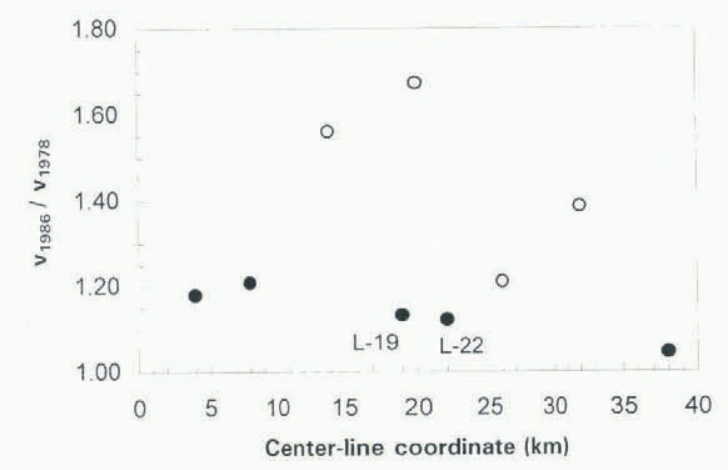

Fig. 5. Fractional change in annual ice speed between 1978 and 1986. Sites along the Denali Faull are plolted with open circles (O). Sites off the fault are shown with solid circles (•). The L-19 and L-22 sites are on the Lokel tribulary (Fig. 1).

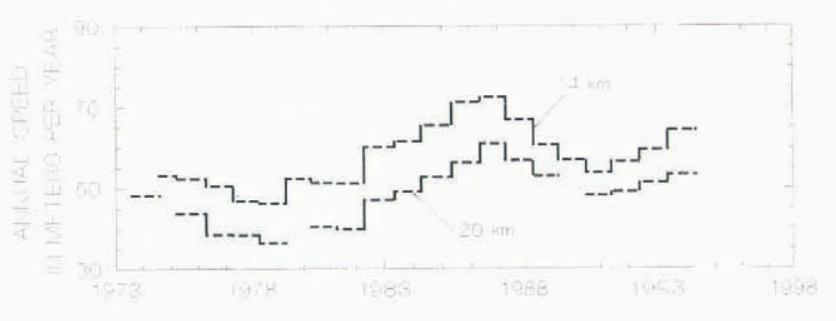

Fig. 6. Anmual surface speeds at the 14 and $20 \mathrm{~km}$ sites. Note parallel rise in speed from 1978-86 and the convergence in speeds during the 1987-91 period of decreasing speed.

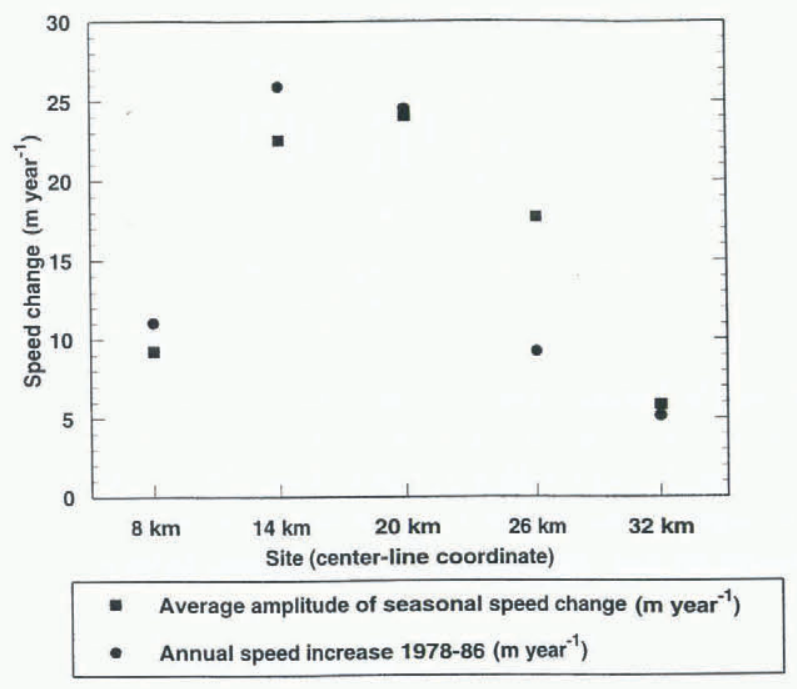

Fig. 7. Comparison of the average amplitude of the seasonal-speed difference and long-term annual speed changes. The average amplitude of the seasonal-speed difference is plotted along with the "long-lerm" increase in annual speed from 1978 to 1986. There is a good correlation between a site's susceptibility to seasonal-speed differences and long-lerm annual speed changes.

survey and the existing USGS maps made in the 1950s (Mount Hayes, B-4 and B-5) is shown in Figure 9 to give a longer time-scale picture of changes. The geometry of the lower ablation area is evolving as expected for a surge-
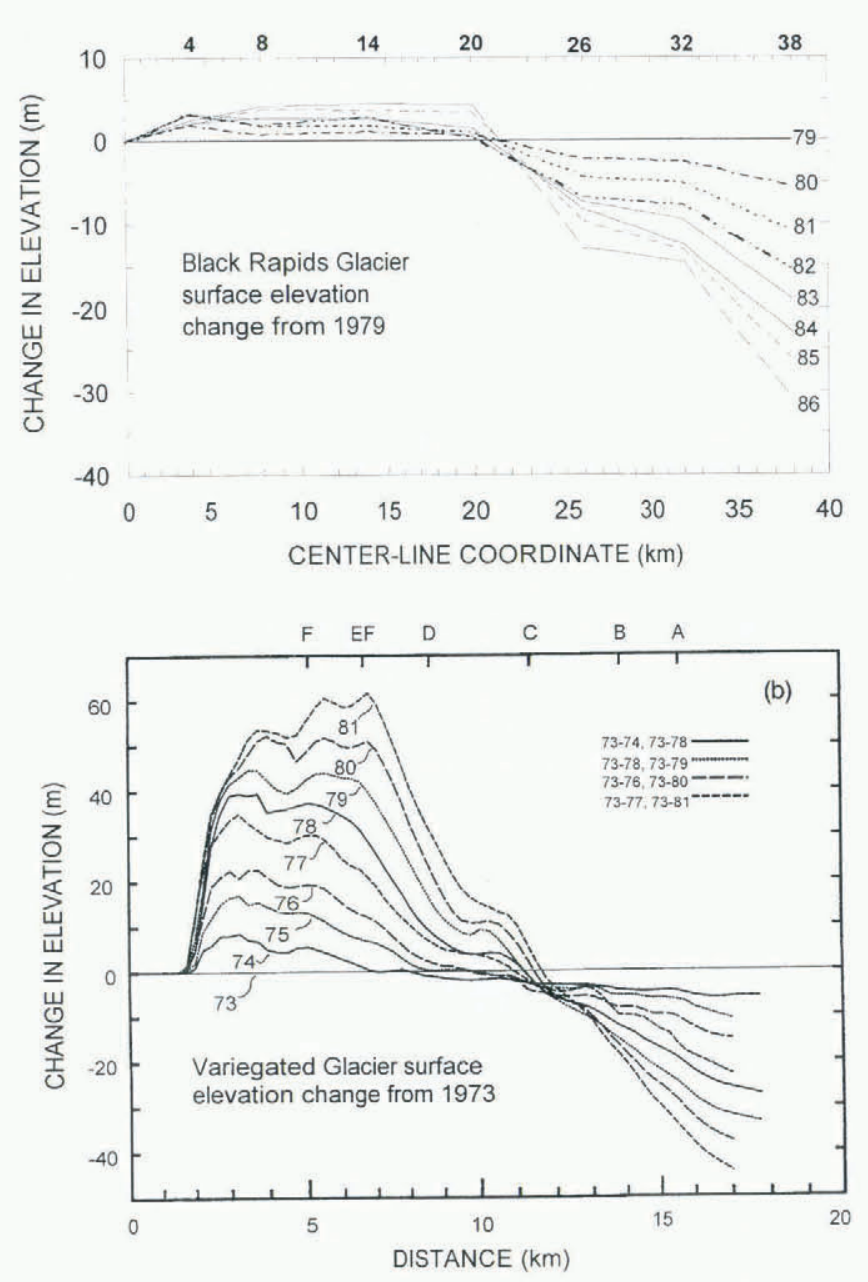

Fig. 8. Surface elevation changes at (a) Black Rapids and (b) Variegaled Glaciers. Black Rapids Glacier change is relative 10 1979. Much of the elevation change at the $26 \mathrm{~km}$ site was due to the encroachment of a trough in front of a medial moraine. Variegated illustration is from Raymond and Harrison (1988). Thinning rates are similar in the surge-receiving areas on both glaciers. The thickening rate in the reservoir area was an order of magnilude larger at Variegated than al Black Rapids Glacier.

type glacier; a monotonic thinning is occurring at all sites below $26 \mathrm{~km}$ (Fig. 4). The rate of thinning has decreased slightly during the period of record at 32 and $38 \mathrm{~km}$. Higher on the glacier, the situation is not as simple. The surface elevation at the $20 \mathrm{~km}$ site has, like the speed, undergone long-term fluctuations (Fig. 4e). The same is true at $14 \mathrm{~km}$, but the amplitude is smaller. In the accumulation area, the $8 \mathrm{~km}$ site is steadily growing thicker. The elevation fluctuated at the $4 \mathrm{~km}$ site. The Loket tributary thinned at the two observed sites until mild thickening began in 1985.

The $26 \mathrm{~km}$ index-site elevation is a special case because it is affected by the Loket tributary and its moraine. In 1972, the site was established about $750 \mathrm{~m}$ down-glacier from the looped, medial moraine being pushed out by the Loket tributary (Fig. 1). A broad trough is located in front of the moraine. As the moraine advanced down-glacier through the $26 \mathrm{~km}$ index site, the elevation at the site decreased as the trough moved into the index-site location. Most of the elevation loss at $26 \mathrm{~km}$ after 1977 is due to this local surface effect. Some of the 


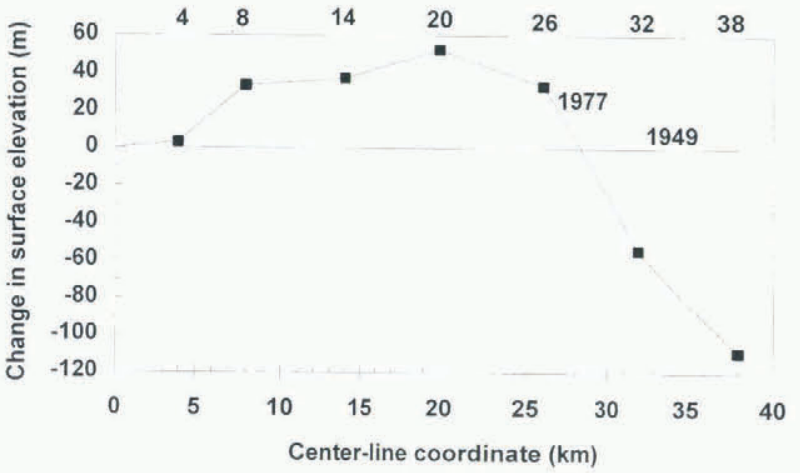

Fig. 9. Thickness change of Black Rapids Glacier from 1949 to 1977. More than a decade passed between the end of the surge and the mapping photography (LSGiS quadrangles, Mounl Hayes B-4 (1954) and B-5 (1951): most of the mapping photographs were laken in 1949). The quality of the vertical control of the maps is unknown. The glacier surface high in the accumulation area was poorly defined in many areas for photogrammetric map-making purposes because il was a fealureless snowfield. Therefore, the accuracy of the comparison may be low, particularly above $10 \mathrm{~km}$.

surface lowering may have been due to long-term mass wastage, but it is not possible to separate the local surface geometry from the mass-wastage effect.

\section{Mass balance}

The Black Rapids Glacier mass-balance observation network, during its most intensive coverage, consisted of ten measurement sites (Table 2 ) on more than $200 \mathrm{~km}^{2}$ of glacier surface. Three of the sites reliably measured mass balance in the accumulation area 4,8 and L-19km). Stakes at $2 \mathrm{~km}$ were frequently buried and lost.) Since 1990, the number of sites monitored has been reduced to three 8,14 and $20 \mathrm{~km}$.) The 8 and $14 \mathrm{~km}$ sites are near the equilibrium line. The relative sparseness of the indexsite data, including a lack of balance data in any uributary other than the Loket, makes accurate calculations of glacier-wide mass balance unfeasible.

In order to make comparison among mass balance, elevation change and speed, it is useful to calculate a parameter, $b_{t}$, which summarizes each year's net mass balance (Fig. 10). Using the net mass-balance data from the $4,8,14,20,26,32$ and $38 \mathrm{~km}$ sites from 1974 to 1989 the shaded area of Table 2 , the value of $b_{t}$ for the year $t$ is the mean of the balance results from all the sites in year $\mathrm{t}$ (he mean of a subset row in Table 2) minus the mean of all the stakes for all the vears considered the entire subset shaded area in Table 2). The actual observation at each site during an individual year can then be represented as $Y_{\mathrm{j} 1}=a_{\mathrm{j}}+b_{\mathrm{f}}+e_{\mathrm{jt}}$, where $a_{\mathrm{j}}$ represents the component of mass balance at the site $\mathrm{j}$ that can be attributed to its physical location and accounts for site-specific factors

Table 2. Vel mass-balance data, Black Rapids Glacier. Results are given in meters of water equizalent. The shaded area of the table was used to calculate $b_{1}$, which represents the lemporal average of mass balance. See tew for details

\begin{tabular}{|c|c|c|c|c|c|c|c|c|c|c|}
\hline \multirow{2}{*}{$\begin{array}{c}\text { Balance } \\
\text { year }\end{array}$} & \multicolumn{10}{|c|}{ Vet mass-balance sile. Black Rapids Glacier } \\
\hline & $2 \mathrm{~km}$ & $4 \mathrm{~km}$ & $8 \mathrm{~km}$ & $14 \mathrm{~km}$ & $20 \mathrm{~km}$ & $26 \mathrm{~km}$ & $32 \mathrm{~km}$ & $38 \mathrm{~km}$ & $\mathrm{~L}-19 \mathrm{~km}$ & L. $-22 \mathrm{~km}$ \\
\hline 1972 & & & & & -2.76 & & -4.25 & & & \\
\hline 1973 & & - & + & 0.77 & 2.09 & 4.08 & -4.65 & & & \\
\hline 1974 & 1.82 & 0.52 & 0.16 & 1.95 & -3.63 & 4.28 & $*$ & * & & \\
\hline 1975 & & 1.20 & 0.44 & 0.55 & 2.40 & -3.12 & 4.42 & 5.42 & & \\
\hline 1976 & & 1.38 & 0.72 & 1.09 & -3.01 & 3.20 & -4.79 & $*$ & & \\
\hline 1977 & 2.47 & 1.87 & 0.93 & -0.51 & -2.09 & 3.00 & -4.45 & -6.02 & & -1.56 \\
\hline 1978 & & 1.10 & 0.34 & -1.38 & 3.17 & -3.71 & -5.13 & 6.06 & & 2.64 \\
\hline 1979 & & 0.92 & 0.06 & 1.98 & $*$ & -4.20 & $*$ & -6.87 & & \\
\hline 1980 & & 2.25 & 0.93 & -0.10 & 1.98 & 3.16 & 3.97 & -6.21 & 0.53 & 1.35 \\
\hline 1981 & 3.22 & 1.87 & 0.89 & 0.19 & 2.23 & -4.13 & 4.90 & 6.49 & 0.29 & -1.85 \\
\hline 1982 & & 1.19 & 0.46 & 0.97 & 2.74 & -4.14 & 5.01 & -6.26 & 0.54 & -2.37 \\
\hline 1983 & & 1.57 & 0.16 & 0.86 & -2.36 & -3.20 & -4.05 & 5.62 & $0.5 \overline{5}$ & 2.06 \\
\hline 1984 & & 1.18 & 0.67 & -0.60 & 2.32 & 3.78 & 4.36 & -5.97 & 0.22 & -1.79 \\
\hline 1985 & & 1.62 & 0.97 & 0.13 & -2.14 & -3.08 & -3.95 & -5.29 & 0.23 & -1.42 \\
\hline 1986 & & 1.78 & 0.71 & -0.46 & -2.65 & 4.34 & -4.42 & -6.29 & 0.83 & 2.26 \\
\hline 1987 & & $*$ & 0.20 & -0.75 & 2.77 & 4.49 & 4.24 & -5.88 & 0.13 & 1.23 \\
\hline 1988 & & $*$ & 0.41 & 0.75 & 2.13 & 4.33 & -3.5 .5 & * & & 2.47 \\
\hline 1989 & & $*$ & 0.91 & -1.40 & $*$ & 4.02 & $*$ & 5.71 & & \\
\hline 1990 & & - & 1.95 & 1.67 & 3.25 & - & - & 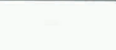 & & \\
\hline 1991 & & & 0.69 & 0.69 & 2.62 & & & & & \\
\hline 1992 & & & 0.78 & 0.89 & -2.24 & & & & & \\
\hline 1993 & & & 0.30 & -1.26 & -3.71 & & & & - & - \\
\hline
\end{tabular}

* Estimated net mass balance values (mw.e.): 1974: $32 \mathrm{~km},-5.45 ; 38 \mathrm{~km},-7.02 ; 1976: 38 \mathrm{~km}, 6.14 ; 1979: 20 \mathrm{~km}$, $-3.26 ; 32 \mathrm{~km},-5.20 ; 1987: 4 \mathrm{~km}, 1.31 ; 1988: 4 \mathrm{~km}, 1.58 ; 38 \mathrm{~km}, 5.94 ; 1989: 4 \mathrm{~km}, 1.24 ; 20 \mathrm{~km}, 2.77 ; 32 \mathrm{~km}-4.71$. 


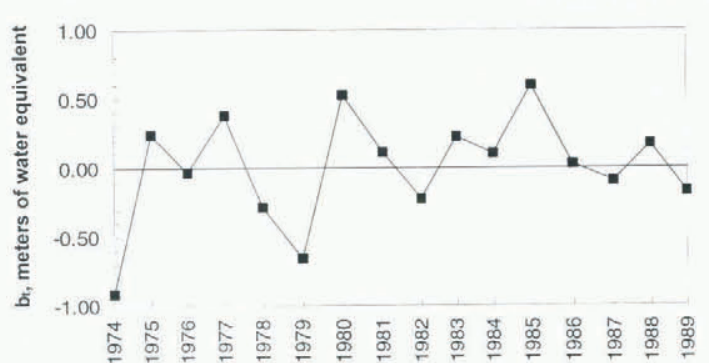

Fïg. 10. Yearly variations of net mass balance, 197489. $b_{1}$ represents the average net mass balance from seven sites. $I t$ is not a glacier-wide average. The mean of the series is zero.

such as elevation and aspect it is the mean of a subset column in Table 2 , and $e_{\mathrm{jt}}$ is an error term with a mean of zero (Lliboutry, 1974; Braithwaite, 1986). The data were not complete, so missing values were replaced with values chosen to minimize the total sum of the squares of the error terms. The values estimated in this way are footnoted on Table 2.

\section{INTERPRETATIONS OF THE OBSERVATIONS}

\section{Relation between mass-balance and elevation changes}

Mass balance is the primary driving force of the surface elevation changes. Although the simple time series of $b_{\mathrm{t}}$

(a) $14 \mathrm{~km}$ Site

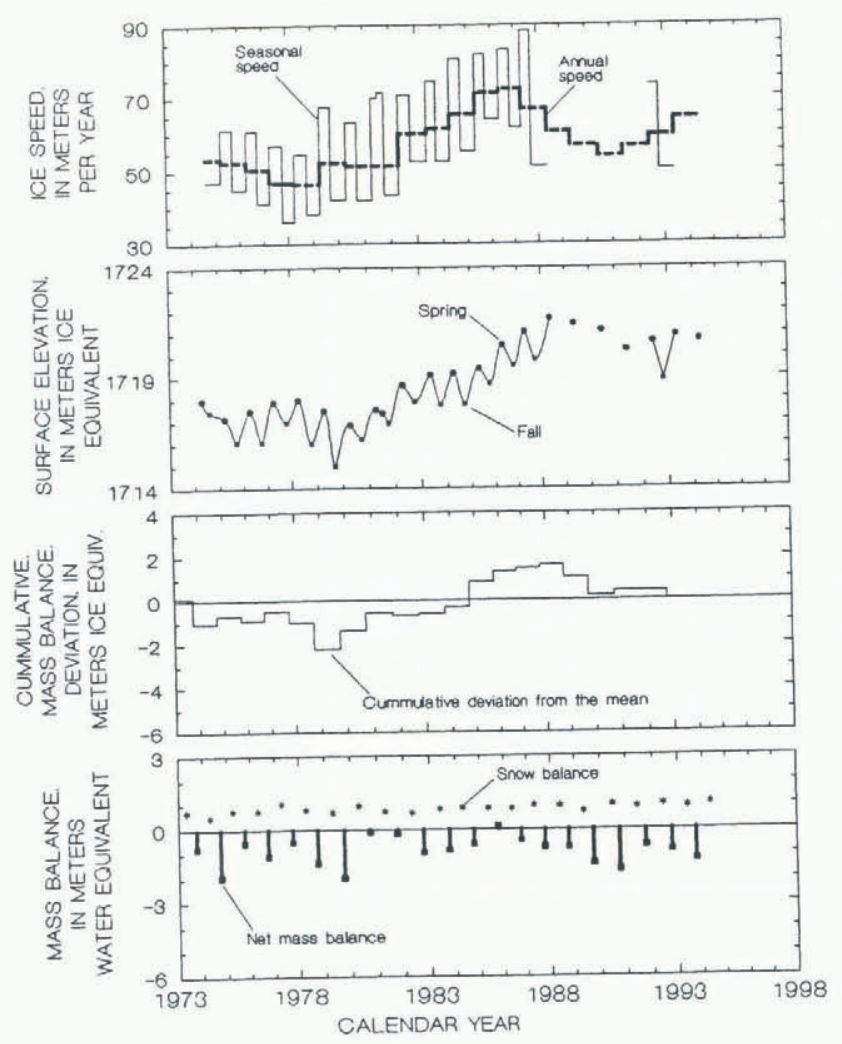

(Fig. 10) does not readily show mass balance to be a driving force of surface elevation change, examining the mass-balance data on a cumulative basis provides a likely explanation for the altitude fluctuations at the 14 and $20 \mathrm{~km}$ sites. In Figure 11, an additional mass-balance term is plotted for the 14 and $20 \mathrm{~km}$ sites: the cumulative deviation from the mean. The difference between each year's mass balance and the mean for the entire site's record (sometimes called the deviate) is accumulated over time. The cumulative deviate correlates well with the elevation at both sites, indicating that the mass balance is driving the elevation changes. Because the amplitude of the cumulative deviate is comparable to the elevation change at the $14 \mathrm{~km}$ site, mass-balance changes are inferred to be the primary driving force of elevation changes. At the $20 \mathrm{~km}$ site, the amplitude of the cumulative deviate is smaller than the elevation change, indicating that mass redistribution by ice flow is also an important factor in the elevation evolution.

\section{Changes in speed: ice deformation and basal motion}

A quantitative analysis demonstrates that changes in basal motion account for the majority of changes in speed at the surface of the glacier. Stresses and speeds were calculated using a method developed by Kamb and Echelmeyer (1986, equations (35a), (35b) and (39)) which accounts for longitudinal stress coupling. Details of stress calculations at Black Rapids Glacier can be found in Heinrichs (unpublished). The basal shear stress in 1977 is shown in Figure 3a.

(b) $20 \mathrm{~km}$ Site

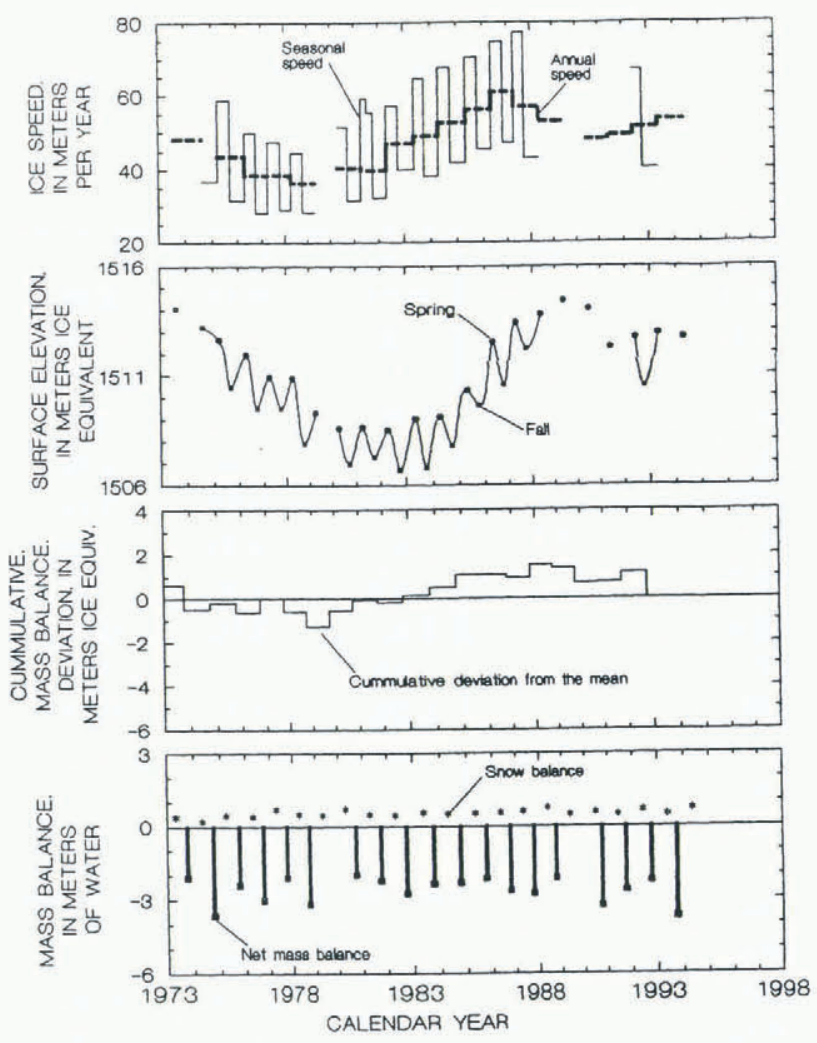

Fig. 11. Cumulative deviation from the mean mass balance. An additional frame has been added to Figure 4d and e, showing the cumulative deviation from the mean mass balance (1973 93). The difference between the mean mass balance and each year's mass-balance result is accumulaled over time. 
The speed at the glacier surface due to ice deformation during the winters of 1977-78 (Fig. 12a) and 1986-87 was calculated with ice properties determined using speeds observed at the $32 \mathrm{~km}$ site. It was assumed that no sliding was occurring at the $32 \mathrm{~km}$ site in the winter of $1977-78$. If sliding were occurring, the ice properties determined from the calibration would overestimate deformability of the ice, so, if anything, the calculated deformational velocities are too high rather than too low. The quantity termed "basal speed" is calculated as the difference between the observed winter speed and the calculated deformational speed. Even during winter, a substantial fraction of the motion is due to basal motion at most sites (Fig. 12b).
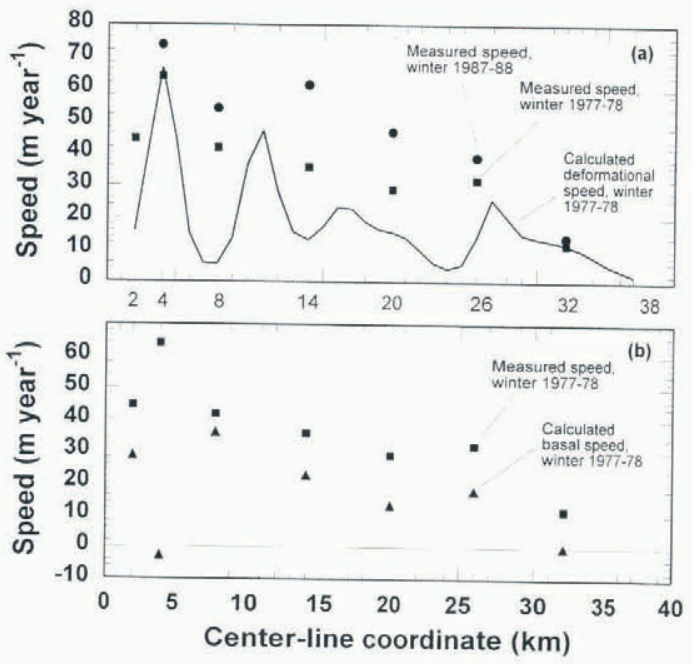

Fig. 12. Winter speeds. In the upper frame (a), measured speeds and calculated deformational speeds are shown. In the lower fiame (b), the basal speed, calculated as the difference between the measured speed and the calculated deformalional speed, is shown. The negative basal speed calculated for the $4 \mathrm{~km}$ sile indicates that ice deformation is underestimated at the sile; we do not believe negalive basal motion is actually occurring.

To determine how much of the winter speed change is due to changes in the rate of ice deformation, the difference between the 1977-78 and 198687 deformational speeds was calculated and compared with the change in measured speed (Fig. 13). It was assumed that changes in observed speed not accounted for by changes in deformational speed are due to changes in the rate of basal motion. Above $26 \mathrm{~km}$, changes in the calculated deformational speed were negligible compared with changes in measured speed. This implies that most of the change in winter speed above $26 \mathrm{~km}$ between 1977 and 1987 was due to changes in basal motion.

Another important aspect of the basal motion is that both winter and summer speeds change with the longterm changes (Fig. 4). This implies that speeds during both seasons are affected by a year-round process that is driving the multi-year speed fluctuations. This type of behavior is apparently not confined to surge-type glaciers, however. Hodge (1974) observed a similar pattern of winter and summer speed changes during a 2 year period

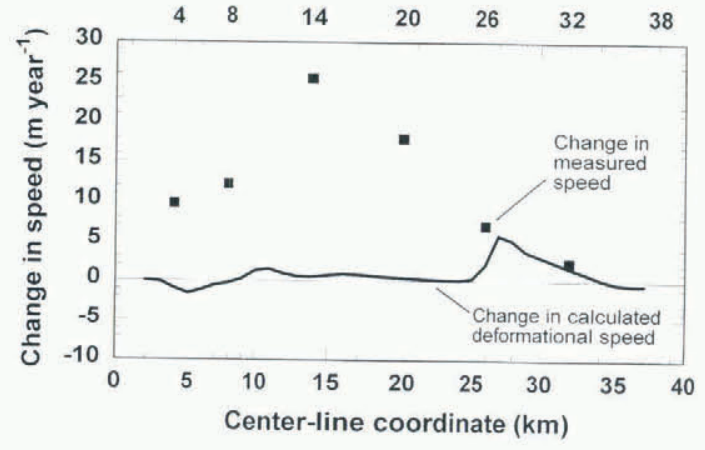

Fïg. 13. Change in winter speed, 1977-87. The changes in deformational speed were small compared with the changes in measured speed. This implies most of the speed change was due to changes in basal motion.

at non-surge-type Nisqually Glacier on Mount Rainier, Washington, U.S.A.

As discussed earlier, a final noteworthy aspect of the basal motion is that seasonal-speed differences at each site are well correlated with the long-term increase in speed (Fig. 7). This aspect can also be seen in Figure 4: the amplitude of the saw-tooth seasonal speed pattern is of comparable size to the amplitude of long-term fluctuations in annual speed. Although it might be expected that the processes driving seasonal and long-term changes are substantially different, the observations indicate that factors important in causing a site to be susceptible to seasonal changes are likely the same as those which cause a site to be susceptible to long-term changes. Therefore, observations of seasonal speed at a site are an important indicator of basal conditions at that site.

\section{Interaction between the Loket tributary and the main trunk}

The largest speed and geometry fluctuations occurred at the 14 and $20 \mathrm{~km}$ sites. The evolution of these two sites is indicative of a unique and important behavior of the reach of the glacier along the Denali Fault above the Loket tributary from $23 \mathrm{~km}$ up through $14 \mathrm{~km}$ and into the pass to Susitna Glacier; Fig. 1), and that the Loket tributary plays a vital role in the quiescent-phase evolution of the glacier. Qualitatively, we believe that the main branch of the glacier is being "dammed" by steady flow into the main branch from the Loket tributary, resulting in thickening above the tributary's entrance into the main branch (Fig. 9). This situation is analogous to "backwater" in river hydraulies in which the elevation of water in one channel controls that in another channel as the two channels merge. The reach above the Loket and up at least as high as $14 \mathrm{~km}$ lies on a bed that is highly susceptible to basal motion Fig. 13), suggesting the possibility that the entering tributary is also influencing bed hydraulics.

On the reach along the Denali Fault above the Loket tributary, the parallel rise of speeds between 1978 and 1986 at the 14 and $20 \mathrm{~km}$ sites indicates a strong longitudinal stress coupling between them; this piece of the glacier moves as nearly a single unit over the bed (Fig. 6). This strong coupling further indicates that significant 
basal motion occurs in this section of the glacier. We infer this because coupling lengths are much longer over "slippery" glacier beds than over beds that allow less basal motion (Kamb and Echelmeyer, 1986). The blockmotion situation was strongly displayed during the first observed period of speed-up from 1978 to 1986 . The coupling was weaker during the periods of slow-down, as indicated by the observation that annual speed changes were not parallel at the two sites during the slow-down periods (before 1978 and 1987-91; Fig. 6). Apparently, during the periods of slow-down, there is less basal motion, which manifests itself in the form of lower speeds and weaker coupling.

Speed changes at the Loket tributary sites L-19 and $\mathrm{L}-22 \mathrm{~km}$ ) appear to lag the main branch, indicating either a weaker or a different coupling mechanism than on the main branch. It is also interesting to note that three of the sites which lie along the Denali Fault $(14,20$ and $32 \mathrm{~km}$ : plotted with open circles in Figure 5) underwent larger speed increases than all the other sites. The exception is the $26 \mathrm{~km}$ site, which is influenced by the Loket tributary. The geology on the south side of the valley in which the Loket tributary and the main accumulation area originate is characterized by relatively competent, intrusive rock. North of the fault, the rock is much less competent, metamorphosed granitic and sedimentary rock Post, 1969; Nokleberg and others, 1992). The fault trench itself is possibly filled with fault gouge, which has many properties in common with clays. Although not conclusive, this evidence suggests that geology has an important influence on longitudinal coupling and speed.

Longitudinal stress coupling is the explanation we favor to explain the coherent changes at the 14 and $20 \mathrm{~km}$ sites. The observations do not rule out other possibilities, for example, mass-balance-induced thickness changes, causing the coupled changes in speed. We would argue, however, that longitudinal stress coupling provides a plausible explanation for the glacier's behavior.

\section{Cause of the speed variations}

Ice deformation driven by geometry changes has been ruled out as the primary cause of the speed variations Fig. 13). There are several possible explanations for the long-term fluctuations in basal speed. The small changes in elevation (which have been shown to be mainly due to mass-balance variations; Fig. 11) and changes in basal shear stress caused by the changing geometry could be directly driving speed changes at the bed. In this scenario, the bed is extremely sensitive to stress changes, so that small elevation changes are enough to cause large changes in basal motion. Another possibility is that mass-balance variations drive changes in the basal motion directly by some process such as water input or storage at the bed. It is also possible that the basal speed fluctuations are not being driven directly by geometry or mass balance and are due to some completely different process, for example. the evolution of the basal drainage network. This possibility of an unrelated process is supported by the varying lag in time between the onset of speed changes and of elevation changes (Fig. 4). At this time we do not know what is causing the speed fluctuations except that the entering Loket tributary apparently dams the main branch, influencing the reach above the entering tributary which is undergoing speed and geometry variations driven by an unknown basal process.

\section{COMPARISONS WITH VARIEGATED GLACIER}

The behavior of Black Rapids Glacier, during that part of its quiescent phase where we have observational data, is significantly different from that of Variegated Glacier, another well-studied surge-type glacier in Alaska. Variegated Glacier most recently surged in 1982-83 Kamb and others, 1985) and, prior to that, in 196465 Post, 1969). The data from Variegated Glacier spanned the last 10 years of its 15 year quiescent phase; the data from Black Rapids Glacier span a smaller part of the latesurge cycle: 22 years of an estimated 50-75year long quiescent phase.

The speed at Variegated Glacier steadily increased during the period observed between its surges (Raymond and Harrison, 1988, fig. 5). In contrast, the speed of Black Rapids Glacier has undergone long-term fluctuations of as much as $45 \%$ about the mean. On Variegated Glacier, the annual speeds increased by up to $500 \%\left(u_{1981} / u_{1973}=\right.$ 5.0 and the annual speed increases were monotonic at all sites Raymond and Harrison, 1988). The largest annual speed increase at Black Rapids Glacier was $u_{1986} /$ $u_{1978}=1.7$ at $20 \mathrm{~km}$, and was followed by a slow-down.

Where Black Rapids Glacier is presently thinning (in the surge-receiving area, below about $28 \mathrm{~km}$ ), the rate of thinning is similar to that observed in the corresponding area of Variegated Glacier. Where Black Rapids Glacier is thickening (in the surge-reservoir area, above $28 \mathrm{~km}$ ), the thickening rate is an order of magnitude less than that observed on Variegated Glacier (Fig. 8).

Variegated Glacier is located in maritime southeast Alaska - a much higher-precipitation environment than the central Alaska Range where Black Rapids Glacier is located. Considerably more net accumulation occurs at Variegated than at Black Rapids Glacier Bindschadler, 1982, fig. 4). This is a possible reason for Variegated Glacier's shorter evolution between surges than that of Black Rapids Glacier. Another possible reason is that Variegated Glacier is considerably smaller than viz. about half the length of) Black Rapids Glacier.

In summary, Variegated Glacier evolved more steadily between its 1965 and 1982 surges than has Black Rapids Glacier since its most recent surge in 1936 37. Our observations on Black Rapids Glacier and those by Clarke and Blake (1991) on Trapridge Glacier, which also show a substantially different quiescent-phase evolution than was observed on the well-known Variegated Glacier, indicate that there may be a variety of mechanisms which cause surge-type behavior in glaciers.

\section{FUTURE SURGES OF BLACK RAPIDS GLACIER}

Three important questions should be asked about the next surge of Black Rapids Glacier. Will it surge again? And if so, when will the surge occur, and how large will it be? First, it is possible that the glacier is not in a quiescent phase between surges and, instead, is evolving towards a 
condition where it is unstable to surge in the present climate. The oscillatory behavior of the speed and geometry would seem to support this idea, or perhaps these fluctuations are the nature of surge-type glaciers with long periods. A conclusion cannot be drawn because of the lack of continuous, long-term observations of longperiod, surge-type glaciers.

Concerning surge timing, the glacier is in a configuration similar to that prior to the 193637 surge; this supports the possibility of an imminent surge. The clearest indicator of this conliguration is the size of the looped moraine being pushed out by the Loket tributary Figs 1 and 2; Post and LaChapelle, 1971). The area of this loop is now the same as the area of the loop carried downglacier from the mouth of the Loket during the 1936-37 surge. This is a simple, obvious indicator of surge timing. However, although the moraine patterns are similar, the slope and elevation configuration may not yet have evolved to the same state as in late 1935. The negative indicator of an imminent surge is the speed fluctuation. Twice during the period of observation, the glacier slowed and moved away from evolution towards a surge state when conditions became unfavorable for continued acceleration. Currently, the glacier is accelerating and could progress into surge state if the climate supports continued thickening and acceleration.

Concerning the size and extent of the terminus advance of the next surge, if the glacier were to advance across the Delta River as it has in the past, both the Richardson Highway and the oil pipeline would be affected. The history of the moraines discussed above Reger and others, 1993 suggests that surge crossings of the Delta River are relatively rare events, at least compared with the surge period, which is probably 50 75 years. To illustrate, if the most recent crossing of the Dela River was $1710 \mathrm{BP}$ (Fig. 1) and a 75 year surge period is assumed, 22 surges that did not cross the river have occurred since $1710 \mathrm{BP}$. On this basis, it would be surprising if the next surge crosses the Delta River and affects transportation facilities in the valley. However, the situation is not so clear when one considers that more recent surges such as that marked by the terminal moraine $\Lambda$ in Figure 1 ) and the action of vigorous streams draining the glacier may have destroyed evidence of many earlier surges. Prediction of the magnitude of a surge never accomplished before, to our knowledge is complicated by many factors: seasonality is an example. Because surges often stop suddenly during carly summer when meltwater becomes abundant Harrison and others, 1994, it follows, for example, that a cool spring and late summer could delay surge termination, resulting in a more extensive surge advance than if the season had been average.

\section{SUMMARY AND CONCLUSIONS}

Speeds and surface elevations have fluctuated during the course of 22 years of observations at Black Rapids Glacier, indicating that quiescent-phase evolution is not necessarily composed of monotonic changes in surface geometry and basal stress, such as those observed at Variegated Glacier. Summarizing the speed observations, there have been coherent, long-term fluctuations in speed at all sites: these long-term fluctuations occur in both the winter and summer speeds Fig. 4). The amplitude of the long-term fluctuation correlates well with the amplitude of the average seasonal-speed difference at a site (Fig. 7). Surface elevation has also undergone long-term fluctuations at some sites (Fig. 4). The glacier is thinning in the surge-receiving area much faster than it is thickening in the reservoir area Fig. 8). Cumulative deviation from the mean is the most important mass-balance term to consider for interpretations (Fig. 11).

Four primary interpretations were drawn from these observations. First, changes in basal motion, rather than changes in ice deformation due to geometry changes, have caused most of the changes in surface speed Fig. 13). Secondly, the interaction between the Loket tributary and the main trunk of the glacier is an important factor in the quiescent-phase evolution. Thirdly, we considered several possible causes of the long-term speed variations. Small changes in elevation caused by mass balance Fig. 11), which cause small changes in basal shear stress, may be directly driving the speed changes at the bed because the bed is extremely sensitive to stress. Alternatively, mass-balance variations could be driving changes in basal motion directly by some process such as water input or storage at the bed. Another possibility is that an unrelated process is driving the speed fluctuations regardless of geometry or mass-balance variations. The fourth interpretation is that mass balance is an important driving force of the surface elevation changes Fig. 11 ).

It is not certain if or when the glacier will surge again. Black Rapids Glacier may not be capable of surging in the present climate, and the indicators of the imminence of the next surge are ambiguous. If it does surge, we believe it is unlikely that the terminus will advance across and dam the Delta River.

\section{ACKNOWLEDGEMENTS}

Scores of people have labored to gather the data presented here; we are grateful to them for the high quality and dedicated efforts they brought to their work at Black Rapids Glacier. D. Trabant and R. March of the USGS deserve special thanks for their two decades of work gathering much of the data presented here. C. Raymond's manuscript review helped focus our presentation. The early years of the project were supported by the Alyeska Pipeline Company, the middle years by the USGS, and the recent years by the USGS and U.S. National Science Foundation grants DPP85-19110, 1)PP88-22584 and OPP922783.

\section{REFERENCES}

Bindschadler. R. 1982. I numerical model of temperate glacier flow applied to the quiesent phase of at surge-1ype glacier. J. Glaciol.. 2899.239265

Bindsehadler. R., W.D. Hamison. C: F. Raymond and R. Cirosson. 1977. Cicometry and dynamics of a surge-upe glacier. \%. Cilaciol.. $1879.181 \quad 194$.

Braillwaite, R.J. 1986, Astessment of mass-balance variations within at sparse stake network. Qamantirstip sermia. West Greenland. J. Glaciol.. $32110,50 \quad 53$. 
Clarke, G. K. C. and E. W. Blake. 1991. Geometric and thermal evolution of a surge-type glacier in its quiescent state: Trapridge Glacier, Yukon Territory, Canada, 1969-89. J. Glaciol., 37 125), $158-169$.

Clarke, T. S. 1991. Glacier dynamics in the Susitna River basin, Alaska, U.S.A. J. Glaciol., $37(125), 97-106$.

Dolgushin, L.D. and G.B. Osipova. 1975. Glacier surges and the problem of their forecasting. International Association of Hydrological Sciences Publication 104 (Symposium at Moscow 1971 - Snow and Ice), 292304.

Dolgushin, L. D. and G. B. Osipova. 1978. Balance of a surging glacier as the basis for forecasting its periodic advance. Mater. Glyatsiol. Issled. $32,260-265$.

Giddings, J. L. 1988. Thunder from below University of Alaska 1937 Black Rapids Glacier Expedition. 7. North. Sci., 2, 3339.

Hance, J. H. 1937. The recent advance of Black Rapids Glacier, Alaska. J. Geol., 45, 775-783.

Harrison. W. D., L. R. Mavo and D. C. Trabant. 1975. Temperature measurements on Black Rapids Glacier, Alaska, 1973. In Weller, G. and S. A. Bowling, eds. Climate of the Arctic. Fairbanks, AK, University of Alaska, 350-352.

Harrison, W. D., K. A. Echelmeyer, E. F. Chacho, C. F. Raymond and R.J. Benedict. 1994. The 1987-88 surge of West Fork Glacier, Susitna Basin, Alaska, U.S.A. J. Glaciol., 40 135), $241-254$.

Heinrichs, T. A. 1994. Quiescent phase evolution of a surge type glacier: Black Rapids Glacier, Alaska, U.S.A. M.Sc. thesis, University of Alaska, Fairbanks.

Heinrichs, T.A., L. R. Mayo, R. S. March and D. C. Trabant. 1995. Observations of surge-type Black Rapids Glacier, Alaska, during a quiescent period, 1972-92. U.S. Geol. Surv. Open File Rep. 94-512.

Hodge, S. M. 1974. Variations in the sliding of a temperate glacier. $\mathcal{F}$. Glaciol., 1369 , 349369.

Kamb. B. and K.A. Echelmeyer. 1986. Stress-gradient coupling in glacier flow: I. Longitudinal averaging of the influence of ice thickness and surface slope. J. (ilaciol., 32(111), 267-284.
Kamb. B. and 7 others. 1985. Glacier surge mechanism: 1982-1983 surge of Variegated Glacier, Alaska. Science, 227 (4686), 469-479.

Lliboutry, L. 1974. Multivariate statistical analysis of glacier annual balances. .. Glaciol., 13 69), 371-392.

Meier, M. F. and A. Post. 1969. What are glacier surges? Can. J. Earth. Sci., 6 4), 807-817.

Moffit, F. H. 1939. Geology of the Gerstle River District, Alaska, with a report on the Black Rapids Glacier, U.S. Geol. Surv. Bull. 926-B, 146157.

Nokleberg, W.J. and 6 others. 1992. Preliminary geologic map of the Mount Hayes quadrangle, eastern Alaska Range, Alaska. U.S. Geol. Surv. Open File Rep. 92-594.

Post, A. 1969. Distribution of surging glaciers in western North America. J. Glaciol., 8 -53), $229-240$.

Post, A. S. and E. R. LaChapelle. 1971. Glacier ice. Seattle, WA, The Mountaineers and University of Washington Press.

Post, A. and L. R. Mayo. 1971. Glacier dammed lakes and outburst floods in Alaska. U.S. Geol. Surv. Hydrol. Invest. Allas HA-455.

Ravmond. C. F, and W. D. Harrision. 1988. Evolution of Variegated Glacier, Alaska, U.S.A., prior to its surge. J. Glaciol., 34(117), 154 169.

Raymond, C. F., R.J. Benedict, W. D. Harrison, K. A. Echelmeyer and M. Sturm. 1995. Hydrological discharges and motion of Fels and Black Rapids Glaciers, Alaska, U.S.A.: implications for the structure of their drainage systems. J. Glaciol., 41 138), 290-304.

Reger, R. D., A. G. Sturmann and J. E. Beget. 1993. Dating Holocene moraines of Black Rapids Glacier, Delta River valley, central Alaska Range. In Solie, D. N. and F. Tannian, eds. Short notes on Alaskan geology 1993. Fairbanks, AK, Alaska Division of Geological and Geophysical Surveys, 51 59. (Professional Report 113.

Sturm, M. 1987. Observations on the distribution and characteristics of potholes on surging glaciers. J. Geophys. Res., 92 B9), 9015-9022.

Sturm, M. and D. M. Cosgrove. 1990. Correspondence. An unusual jökulhlaup involving potholes on Black Rapids Glacier, Alaska Range, Alaska, U.S.A. J. Glaciol., 36 122), 125-126. 